\title{
Increase Student Learning Interest in Covid-19 with Digital Teaching Materials
}

\author{
I Nyoman Kiriana $\mathbf{1}^{\mathbf{*}}$ \\ ${ }^{1}$ Universitas Hindu Negeri I Gusti Bagus Sugriwa Denpasar, Indonesia \\ e-mail: kiriana@uhnsugriwa.ac.id
}

\section{A R T I C L E IN F O}

Article history:

Received April 10, 2021

Revised April 11, 2021

Accepted May 12, 2021

Available online May 25, 2021

Kata Kunci:

Bahan Ajar, Digital, Minat belajar

Keywords:

Teaching Materials, Digital, student learning interest

\begin{abstract}
A B S T R A K
Pelaksanaan pembelajaran pada mata kuliah pendidikan agama hindu yang cenderung kurang menarik minat mahasiswa untuk belajar. Tujuan penelitian ini untuk mengembangkan bahan ajar digital pada mata kuliah pendidikan agama hindu untuk meningkatkan minat belajar mahasiswa. Penelitian ini merupakan penelitian pengembangan (research and devlopment). Subyek uji coba penelitian merupakan mahasiswa dari Prodi Pendidikan Agama. Data yang dikumpulkan dalam penelitian ini adalah data dari uji ahli isi mata pelajaran, uji ahli desain, uji ahli media pembelajaran, dan dari ujicoba mahasiswa. Instrumen pengumpulan data yang digunakan berupa lembar evaluasi (angket). Analisis data menggunakan analisis deskriptif kualitatif dan deskriptif kuantitatif. Hasil penilaian yaitu: aspek isi bidang studi/ dengan persentase tingkat pencapaian $87.00 \%$ dengan predikat layak; aspek desain pembelajaran dengan persentase tingkat pencapaian $85.55 \%$ predikat layak; aspek media pembelajaran dengan persentase tingkat pencapaian $88.00 \%$ predikat layak; aspek uji coba perorangan $90.65 \%$ pedikat sangat layak; uji coba kelompok kecil yaitu $95.55 \%$ predikat sangat layak; dan aspek uji coba lapangan dengan persentase tingkat pencapaian $94.45 \%$ predikat sangat layak. Bahan ajar ini memiliki tingkat validitas yang baik dan layak untuk digunakan dalam proses pembelajaran pada mata kuliah pendidikan agama. Implikasi penelitian ini yaitu bahan ajar digital yang dikembangkan dapat digunakan untuk meningkatkan serta memudahkan siswa dalam belajar.
\end{abstract}

\section{A B S T R A C T}

The problem behind this research was the implementation of learning courses that tend to attract less students to study. This research was research and development. The subject of the research trial was a student of the Religious Education Study Program. The data collected in this research were data from expert test subject content, design expert test, learning media expert test, and from student trials. Data collection instrument used in the form of evaluation sheet (questionnaire). Data analysis used qualitative and descriptive quantitative descriptive analysis. The results of the assessment of media products were carried out based on six aspects, namely: aspects of the content of the field of study / with a percentage of achievement rate of $87.00 \%$ with a worthy predicate; reviewed from the aspect of learning design with a percentage of achievement rate of $85.55 \%$ worthy predicate; reviewed from the aspect of learning media with a percentage of achievement rate of $88.00 \%$ worthy predicate; reviewed from the aspect of individual trials, with a percentage rate of $90.65 \%$ pedikat very feasible; small group trials, with a percentage achievement rate of $95.55 \%$ predicate is very feasible;and reviewed from the aspect of field trials with a percentage achievement rate of $94.45 \%$ predicate is very feasible. Thus this product in the form of teaching materials has a good level of validity and deserves to be used in the learning process in religious education courses.

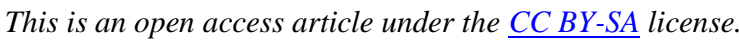

Copyright (C) 2021 by Author. Published by Universitas Pendidikan Ganesha.

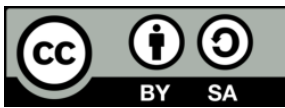

\section{INTRODUCTION}

Learning is a process that provides opportunities for students to explore and build their own knowledge. With the ability to build their own knowledge, it will provide good experience and emotional development (Bressington et al., 2018; Kostiainen et al., 2018). Currently learning is experiencing a very big challenge where the learning process that should be face-to-face shifts to online learning (Abidah et al., 2020; Durnali, 2020). Online learning is one of the solutions offered in the pandemic (Alavudeen et al., 2021; Ariebowo, 2021). Online learning is learning carried out with the help of the internet both synchronously and asynchronously which provides opportunities for student interaction with learning resources, both educators/environments and peers without any space and time limits and is more flexible (Dong et al., 2020; Hwang et al., 2020; Kkese, 2020; Lage-Cala et al., 2020). Online learning will not run well is largely determined 
by the ability of educators and students, because the ability to use technology will greatly help create a more conducive learning atmosphere, so that good social interactions are formed (Andel et al., 2020). With online learning will help students continue to get the maximum learning. Education during the pandemic is carried out online so technology plays a very important role (Hamidaturrohmah \& Mulyani, 2020; Sadikin \& Hamidah, 2020). This is because the implementation of education is carried out by utilizing social media, both whatsapp to zoom media and google meet. In this case the teacher cannot interactively explain the material to students so that learning media or teaching materials are needed to support the implementation of learning (Anitha Kumari et al., 2020; Jang et al., 2021). Teaching materials are a set of learning tools or tools that contain learning materials, methods, limitations and evaluation methods that are designed systematically and attractively in order to achieve the expected goals, namely achieving competencies or sub-competencies with all their complexity.(Istuningsih et al., 2018; Neppala et al., 2018).

Teaching materials are one of the important factors in learning (Hidayah \& Priscylio, 2019). The existence of teaching materials makes teachers able to convey material well to students (Martha \& Andini, 2019). Teaching materials are knowledge, skills, and attitudes that must be learned in order to achieve predetermined competency standards (Asriani et al., 2017b), and teaching materials can attract students' attention in learning because they have attractive designs and pictures (Gustiawati et al., 2020). The importance of teaching materials in the learning process requires teachers to develop teaching materials that are in accordance with the needs of students, curriculum demands, not depending on textbooks and government aid packages, and according to the characteristics of students (Andani \& Yulian, 2018; M. Cloonan \& Fingeret, 2020; Weriyanti et al., 2020). With the existence of teaching materials that are in accordance with the curriculum, needs and characteristics will be able to increase student motivation and students can obtain learning in accordance with the development of science and technology (Suzuki et al., 2020). In addition, teaching materials can increase the creativity of students (Tsai et al., 2017). So, the presence of quality teaching materials will be able to have an impact on motivation, interest, creativity which results in student learning outcomes (Priantini, 2021).

The problem that occurs today is that there are still many educators who have difficulty making interesting learning materials that can motivate students in learning (Asriani et al., 2017a; Lukman \& Ishartiwi, 2014; Purwanto \& Rizki, 2015). This causes students' interest in learning to decrease (A. D. Aprilia et al., 2018; Nurdyansyah \& Mutala'liah, 2015). Based on the results of observations and document studies that have been carried out in the Religious Education study program, Universitas Hindu Negeri I Gusti Bagus Sugriwa, it was found that the interest in learning from students of the religious education study program was very low. Based on the results of filling out questionnaires, it can be concluded that there are several problems behind the lack of interest in student learning (Santika et al., 2021). These problems include the lack of interest in the learning provided, the implementation of lectures tends to be dominated by lecturers with the lecture method so that students get bored quickly. However, the problem that is felt to greatly affect student interest in learning is with lectures carried out using an online system, which causes students to lack learning resources because students do not get books from institutions so that students have a little difficulty in doing the assignments given, therefore there is a need for learning resources (Priantini, 2017).

The solution that can be offered is by developing digital teaching materials that contain materials, especially in Hindu religious subjects. Previous research has stated that digital teaching materials can help students learn (Fadillah \& Jamilah, 2016; Mastroleo et al., 2020; Thuneberg et al., 2018). Digital teaching materials are all forms of content, both text, audio, photos, videos, animations, and others that can be used for learning which includes learning instructions (student/teacher instructions), competencies to be achieved, content or content of learning materials, supporting information, exercises, work instructions, can be in the form of worksheets, evaluations, responses or feedback on the evaluation results (Istuningsih et al., 2018; Neppala et al., 2018). Digital teaching materials can also be regarded as learning resources that can be used by students both in classroom learning or independently without a lecturer or tutor (Alias \& Siraj, 2012; Liu et al., 2021). The purpose of developing digital teaching materials is to make the learning process more flexible, this is supported by technology-based teaching materials that are currently quite diverse by bringing up visuals, images, videos, and animations that are intended to convey learning messages to students or students (Kiong et al., 2012; Lee \& Osman, 2012; Mastroleo et al., 2020). Digital teaching materials were chosen because they have several advantages over printed teaching materials (Swarniti, 2021b). There are several advantages of digital teaching materials, including learners can learn anytime and anywhere as long as they have internet access, cost efficiency, learners can choose subject matter according to the material being studied, are able to facilitate and apply different learning styles through exercise, activities, and are able to develop and maximize the ability of learners related to ICT (Aprilia \& Suryadarma, 2020; Cloonan et al., 2020).

Previous research findings state that digital teaching materials make it easier for students to understand learning materials (Herawati \& Muhtadi, 2018; Sidiq \& Najuah, 2020). Other research states that innovative teaching materials can increase students' enthusiasm and motivation in learning (Canboy et al., 2016; M. R. Cloonan et al., 2020). Other research findings also state that E-modules can improve student learning outcomes 
(Imansari \& Sunaryantiningsih, 2017; Kimianti \& Prasetyo, 2019). The absence of studies on digital teaching materials can increase student interest in learning during the Covid-19 pandemic (Swarniti, 2021a). The advantage of this research was that the teaching materials developed are adapted to the characteristics of students, making it easier for students to understand the material presented in the developed teaching materials (Santika, 2018). In addition, the development of this teaching material also uses message design theory that will attract students' attention in learning. The novelty in this research was that it is carried out especially in Hindu religious education courses, because most of what happens in religious subjects is only based on books. The purpose of this research was to develop digital teaching materials in Hindu religious education courses to increase student interest in Hindu Religious Education Study Program. It is hoped that the developed digital teaching materials can increase student interest in learning so that it has an impact on improving student learning outcomes.

\section{METHOD}

This research was a type of development research. This research method was used to produce certain products, and test the effectiveness of these products. The research carried out took the target at the university level. The research subjects were students of the Hindu Religious Education study program at Universitas Hindu Negeri I Gusti Bagus Sugriwa for academic year 2019/2020 in the even semester. The development model used was the ADDIE model, consisting of the analysis, design, development, implementation and evaluation stages (Wulandari et al., 2020). The research flow using the ADDIE development model is presented in Figure 1.

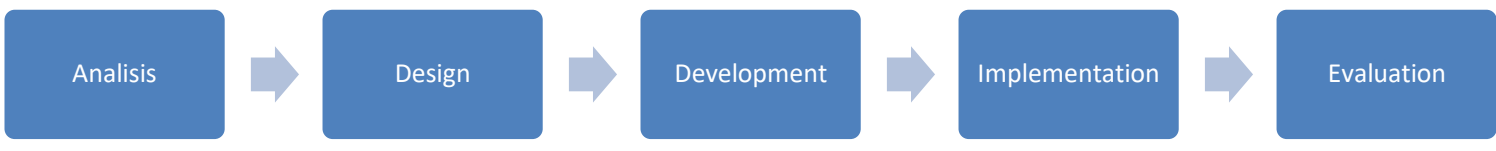

Figure 1. ADDIE Development Model

Data collection techniques used were observation, interviews, and questionnaires. Observation is for development purposes from the early stages in identifying problems to the testing stage. The interview guide instrument was used to collect various information related to the content of the video to be developed, to explore the product review during the trial (completed things that needed further explanation from the questionnaire). Instrument for developing a questionnaire, which is used to determine the percentage of product feasibility in expert trials and audience (student) trials. In the product validity test, the development of learning videos was validated through a review of experts, namely: (a) subject content experts, (b) learning media experts (c) learning design experts. In addition, validation is also done through product trials including: (a) individual trials, (b) small group trials, (c) field trials.

At the product effectiveness test stage, effectiveness is carried out by collecting student learning outcomes data using pre-test and post-test on the material to be tested. The pretest tested the students' initial abilities before using interactive learning media. On the other hand, the post-test is the final activity to test students' abilities on the material that has been given using learning videos. In this development research, the effectiveness test uses descriptive qualitative techniques and inferential statistics. There are two types of data generated, namely in the form of qualitative data and quantitative data. The data analysis technique used is qualitative descriptive analysis technique and quantitative descriptive data analysis. Qualitative descriptive analysis techniques were used to process data from the review of content experts in the field of study or subjects, learning product design experts, learning media experts and student test results. The results of this analysis were then used to revise the product developed. Quantitative descriptive analysis was used to process the data obtained through a questionnaire in the form of scores. The results of the data analysis are seen from the results of the high and low percentage of needs desired by the subject who is the target of this study.

\section{RESULT AND DISCUSSION}

The result of this development research is a product of digital teaching materials in Hindu religious education courses which were developed based on the stages of the ADDIE development model. The results of the research that have been made can be presented in three main topics, namely data presentation and data analysis, product revisions, and discussion of products that have been made. The presentation and analysis of data is further described into four sub-discussions. The four sub-tests include subject content expert tests, learning design expert tests, learning media expert tests, and field trials. The results of the validity of the development of learning videos according to subject matter expert tests, learning design expert tests, learning 
media expert tests, individual trials, small group trials and field trials, more detailed validity results can be seen in the following table.

Table 1. Product Trial Validity Results

\begin{tabular}{lll}
\hline Trial Subject & Validity Results (\%) & Information \\
\hline Course content expert & 87,00 & Good/Worthy \\
Learning design expert test & 85,55 & Good/Worthy \\
Teaching materials expert test & 88,00 & Good/Worthy \\
Individual trial & 90,65 & Very good/Very worthy \\
Small Group Trial & 95,55 & Very good/Very worthy \\
Field Trial & 94,45 & Very good/Very worthy \\
\hline
\end{tabular}

At the stage of the content expert test, the results of product validity in the form of digital teaching materials get a percentage of the achievement level of $87.00 \%$ with good/worthy qualifications/predicates so there is no need for revision. The second stage is the Learning Design Expert Test which is carried out after getting an assessment from the subject content expert test. The results of product validity in the form of digital teaching materials get the percentage level of achievement is $85.55 \%$ with good qualifications so there is no need for revision. In the third stage, the expert test was carried out after the trial of subject content experts and learning design experts. This teaching material product was tested on a learning media expert. The results of the validity of the product developed are $88.00 \%$ with good qualifications so that this media does not need to be revised. The fourth stage is a trial for individuals. The result of the assessment given is that the percentage of achievement level is $90.65 \%$ with very good/very decent qualifications so there is no need to revise. The fifth stage is the Small Group Trial. The assessment carried out by 20 people is still focused on the material aspect. The results of the validity of the product developed are $95.55 \%$ with very good qualifications so that this media does not need to be revised. The last stage is the Field Trial. The assessment carried out remains focused on the overall material and media aspects, both physical and non-physical, as well as from the technical aspect of operation. The result of product validity is $94.45 \%$ with very good/very decent qualification/predicate so that this media does not need to be revised. Based on the results of the validity of the product developed, it can be concluded that the digital teaching materials developed are suitable for use in the learning process. This is caused by several factors, namely as follows.

First, the digital teaching materials developed are suitable for use in the learning process because they can make it easier for students to learn. Basically, teaching materials are needed by educators to assist in conveying material to students (Lukman \& Ishartiwi, 2014; Purnomo \& Wilujeng, 2016). Teaching materials are all forms of materials used to assist teachers or instructors in carrying out the learning process in the classroom which contains a set of materials that are systematically arranged, both written and unwritten, so as to create an environment or atmosphere that allows students to learn (Qondias, D. Winarta, I, K, 2019; Sriyanto et al., 2019). The development of digital teaching materials aims to be able to direct students to be able to solve open problems, be oriented to student characteristics, make students and lecturers technology literate, accelerate the 5.0 era and improve skills in the field of technology (Anandari et al., 2019; Puryadi et al., 2018). Digital teaching materials are good and easy to use because they are more accessible, easy to carry, durable, and easy to obtain for free via the internet (Komikesari et al., 2020; Nisa et al., 2020). Digital teaching materials combine several learning media (audio, video, text or graphics) to control a command from a presentation that is able to provide insight for prospective teachers about the design of technology-assisted learning materials (Setiyani et al., 2020; Thuneberg et al., 2018). Digital teaching materials are needed to help students understand material with various technologies and applications, as well as create curiosity in engineering the technology and concepts being studied.

Second, the digital teaching materials developed are suitable for use in the learning process because they can increase student interest in learning. This digital teaching material is considered very suitable for its application in religious education courses (Santika, 2017). Students tend to feel bored and do not understand the material presented by the lecturer without being given teaching materials so that it reduces interest in learning. With the use of digital teaching materials, students can access anytime and anywhere the material to be taught (Hamdunah et al., 2016; Mastroleo et al., 2020). Digital-based teaching materials to make the learning process more flexible. Digital teaching materials are used in learning with the aim of attracting students to learn actively, learn independently, and have a high degree of adaptation to the development of science and technology.(Neppala et al., 2018; Ningsih \& Mahyuddin, 2021; Silalahi, 2020). Technology-based teaching materials are now quite diverse by bringing up visuals, images, videos, and animations that are intended to convey learning messages to students so that they can attract students' interest in learning and the 
implementation of religious education study lectures will be easier (Astra et al., 2020; Triwahyuningtyas et al., 2020).

The findings of previous research also stated that the module made it easier for students to learn (Boyd, 2019; Seruni et al., 2020). Other research findings also state that teaching materials are needed to attract students' attention in learning (Hamid et al., 2021; Istuningsih et al., 2018). Other research also states that interactive teaching materials can increase students' enthusiasm for independent learning (Asrial et al., 2020; Perdana et al., 2017). The advantages of interactive teaching materials developed are that these teaching materials are in accordance with predetermined indicators and learning objectives, and the presentation of the material presented is simpler to produce teaching materials that are easy to understand and more interesting to learn (Santika, 2021). This shows that the contribution of the use of digital teaching materials is felt to have a positive impact on the implementation of learning both in general subjects and in local content subjects. The update in this research is that digital teaching materials were first used in religious education subjects because they were slightly hampered and affected students' interest in learning in the midst of a pandemic like now. The implication of this research is that the use of digital teaching materials makes the material presentation more interesting and more loaded either in the form of material or in the form of videos that can have a positive impact and increase student interest in learning. This research can later be used as a reference or reference for other researchers and can develop this research with updates in accordance with the demands of learning at that time.

\section{CONCLUSION}

Digital teaching materials developed in Hindu religious education courses are qualified both by experts and based on product trials. Digital teaching materials developed can be used in the learning process so as to increase student interest and motivation in learning. It is recommended for lecturers to use digital teaching materials to make it easier for students to study independently.

\section{REFERENCES}

Abidah, A., Hidaayatullaah, H. N., Simamora, R. M., Fehabutar, D., \& Mutakinati, L. (2020). The Impact of Covid-19 to Indonesian Education and Its Relation to the Philosophy of "Merdeka Belajar." Studies in Philosophy of Science and Education, 1(1), 38-49. https://doi.org/10.46627/sipose.v1i1.9.

Alavudeen, S. S., Easwaran, V., Mir, J. I., Shahrani, S. M., Ahmed Mohammed Almodeer Aseeri, A. A., Khan, N. A., \& Asiri, A. A. (2021). The influence of COVID-19 related psychological and demographic variables on the effectiveness of e-learning among health care students in the southern region of Saudi Arabia. Saudi Pharmaceutical Journal. https://doi.org/10.1016/j.jsps.2021.05.009.

Alias, N., \& Siraj, S. (2012). Effectiveness of Isman Instructional Design Model in Developing Physics Module based on Learning Style and Appropriate Technology. Procedia - Social and Behavioral Sciences, 64. https://doi.org/10.1016/j.sbspro.2012.11.002.

Anandari, Q. S., Kurniawati, E. F., Piyana, S. O., Melinda, L. G., Meidiawati, R., \& Fajar, M. R. (2019). Development of Electronic Module: Student Learning Motivation Using the Application of Ethnoconstructivism-Based Flipbook Kvisoft. Jurnal Pedagogik, 06(02), 416-436.

Andani, D. T., \& Yulian, M. (2018). Pengembangan Bahan Ajar Electronic Book Menggunakan Software Kvisoft Flipbook Pada Materi Hukum Dasar Kimia di SMA Negeri 1 Panton Reu Aceh Barat. Jurnal IPA \& Pembelajaran IPA, 2(1), 1-6. https://doi.org/10.24815/jipi.v2i1.10730.

Andel, S. A., de Vreede, T., Spector, P. E., Padmanabhan, B., Singh, V. K., \& Vreede, G. J. de. (2020). Do social features help in video-centric online learning platforms? A social presence perspective. Computers in Human Behavior, 113(April), 106505. https://doi.org/10.1016/j.chb.2020.106505.

Anitha Kumari, T., Hemalatha, C. H., Subhani Ali, M., \& Naresh, R. (2020). Survey on impact and learning's of the online courses on the present era. Procedia Computer Science, 172, 82-91. https://doi.org/10.1016/j.procs.2020.05.167.

Aprilia, A. D., Iriani, R., \& Nurdiniah, S. H. (2018). Pengembangan Bahan Ajar Berbasis Advanced Organizer Bervisi Sets (Science, Environment, Technology, And Society) Pada Materi Koloid. QUANTUM: Jurnal Inovasi Pendidikan Sains, 9(1).

Aprilia, I., \& Suryadarma, I. G. P. (2020). E-Module of Mangrove Ecosystem (EMME): Development, Validation, and Effectiveness in Improving Students' Self-Regulated. Biosfer: Jurnal Pendidikan, 13(1), 114-129. https://doi.org/10.21009/biosferjpb.v13n1.114-129.

Ariebowo, T. (2021). Autonomous learning during COVID-19 pandemic : Students 'objectives and preferences. Journal of Foreign Language Teaching and Learning, 6(1), 56-77. https://doi.org/10.18196/ftl.v6i1.10079.

Asrial, Syahrial, Maison, M., Kurniawan, D. A., \& Piyana, S. O. (2020). Ethnoconstructivism E-Module to 
Improve Perception, Interest, And Motivation of Students in Class V Elementary School. Jurnal Pendidikan Indonesia, 9(1), 30-41. https://doi.org/10.23887/jpi-undiksha.v9i1.19222.

Asriani, P., Sa'dijah, C., \& Akbar, S. (2017a). Bahan Ajar Berbasis Pendidikan Karakter Untuk. Jurnal Pendidikan: Teori, Penelitian, Dan Pengembangan, 2(11), 1456-1468. http://dx.doi.org/10.17977/jptpp.v2i11.10160.

Asriani, P., Sa'dijah, C., \& Akbar, S. (2017b). Bahan Ajar Berbasis Pendidikan Karakter Untuk Siswa KElas IV Sekolah Dasar. Jurnal Pendidikan: Teori, Penelitian, Dan Pengembangan, 2(11), 1456-1468. http://dx.doi.org/10.17977/jptpp.v2i11.10160.

Astra, I. M., Raihanati, R., \& Mujayanah, N. (2020). Development of Electronic Module Using Creative Problem-Solving Model Equipped with Hots Problems on The Kinetic Theory of Gases Material. Jurnal Penelitian \& Pengembangan Pendidikan Fisika, 6(2), 181-194. https://doi.org/10.21009/1.06205.

Boyd, L. (2019). Using Technology-Enabled Learning Networks to Drive Module Improvements in the UK OpenUniversity. Journal of Interactive Media in Education, 2019(1), 1-7. https://doi.org/10.5334/jime.529.

Bressington, D. T., Wong, W. kit, Lam, K. K. C., \& Chien, W. T. (2018). Concept mapping to promote meaningful learning, help relate theory to practice and improve learning self-efficacy in Asian mental health nursing students: A mixed-methods pilot study. Nurse Education Today, 60(February 2017), 4755. https://doi.org/10.1016/j.nedt.2017.09.019.

Canboy, B., Montalvo, A., Buganza, M. C., \& Emmerling, R. J. (2016). 'Module 9': a new course to help students develop interdisciplinary projects using the framework of experiential learning theory. Innovations in Education and Teaching International, 53(4), 445-457. https://doi.org/10.1080/14703297.2014.975150.

Cloonan, M., \& Fingeret, A. L. (2020). Developing teaching materials for learners in surgery. Surgery (United States), 167(4), 689-692. https://doi.org/10.1016/j.surg.2019.05.056.

Cloonan, M. R., Cloonan, D. J., Schlitzkus, L. L., \& Fingeret, A. L. (2020). Learners with Experience in Surgical Scrub Benefit from Additional Education with an Interactive E-Learning Module. Journal of the American College of Surgeons, 4(2). https://doi.org/10.1016/j.jamcollsurg.2020.08.521.

Dong, C., Cao, S., \& Li, H. (2020). Young children's online learning during COVID-19 pandemic: Chinese parents' beliefs and attitudes. Children and Youth Services Review, 118(August), 105440. https://doi.org/10.1016/j.childyouth.2020.105440.

Durnali, M. (2020). The effect of self-directed learning on the relationship between self-leadership and online learning among university students in Turkey. Tuning Journal for Higher Education, 8(1), 129-165. http://dx.doi.org/10.18543/tjhe-8(1)-2020pp129-165.

Fadillah, \& Jamilah. (2016). Pengembangan Bahan Ajar Struktur Aljabar Untuk Meningkatkan Kemampuan Pembuktian Matematis Mahasiswasyarifah. Cakrawala Pendidikan, 35(1), 106-108.

Gustiawati, R., Arief, D., \& Zikri, A. (2020). Pengembangan Bahan Ajar Membaca Permulaan dengan Menggunakan Cerita Fabel pada Siswa Sekolah Dasar. Jurnal Basicedu, 4(2), 355-360. https://doi.org/10.31004/basicedu.v4i2.339.

Hamdunah, Yunita, A., Zulkardi, \& Muhafzan. (2016). Development a Constructivist Module and Web on Circle and Sphere Material with Wingeom Software. Journal on Mathematics Education, 7(2), 109116. https://doi.org/10.22342/jme.7.2.3536.109-116

Hamid, S. N. M., Lee, T. T., Taha, H., Rahim, N. A., \& Sharif, A. M. (2021). E-Content Module For Chemistry Massive Open Online Course (Mooc): Development And Students' Perceptions. Journal of Technology and Science Education, 11(1), 67-92. https://doi.org/10.3926/jotse.1074.

Hamidaturrohmah, \& Mulyani, T. (2020). Strategi Pembelajaran Jarak Jauh Siswa Berkebutuhan Khusus Di SD Inklusi Era Pandemi Covid-19. Elementary: Islamic Teacher Journal, 10(1). https://doi.org/10.21043/elementary.v8i2.7907.

Herawati, N. S., \& Muhtadi, A. (2018). Pengembangan Modul Elektronik (E-Modul) Interaktif Pada Mata Pelajaran Kimia kelas XI SMA. Jurnal Inovasi Teknologi Pendidikan, 5(2), 180-191. https://doi.org/10.21831/jitp.v5i2.15424.

Hidayah, D. N., \& Priscylio, G. (2019). Pengembangan Bahan Ajar Mandiri Pokok Bahasan Suhu Dan Kalor Menggunakan Software Camtasia. Journal of Teaching and Learning Physics, 4(1), 50-64. https://doi.org/10.15575/jotalp.v4i1.4093.

Hwang, G. J., Wang, S. Y., \& Lai, C. L. (2020). Effects of a social regulation-based online learning framework on students' learning achievements and behaviors in mathematics. Computers and Education, 160, 104031. https://doi.org/10.1016/j.compedu.2020.104031.

Imansari, N., \& Sunaryantiningsih, I. (2017). Pengaruh Penggunaan E-Modul Interaktif Terhadap Hasil Belajar Mahasiswa Pada Materi Kesehatan dan Keselamatan Kerja. VOLT: Jurnal Ilmiah Pendidikan Teknik 
Elektro, 2(1), 11-16. http://dx.doi.org/10.30870/volt.v2i1.1478.

Istuningsih, W., Baedhowi, B., \& Sangka, K. B. (2018). The effectiveness of scientific approach using e-module based on learning cycle 7e to improve students' learning outcome. International Journal of Educational Research Review, 3(3). http://dx.doi.org/10.24331/ijere.449313.

Jang, M., Aavakare, M., Nikou, S., \& Kim, S. (2021). The impact of literacy on intention to use digital technology for learning: A comparative study of Korea and Finland. Telecommunications Policy, 45(7). https://doi.org/10.1016/j.telpol.2021.102154.

Kimianti, \& Prasetyo. (2019). Pengembangan E-Modul IPA Berbasis Problem Based Learning Untuk Meningkatkan Literasi Sains Siswa. Kwangsan Jurnal Teknologi Pendidikan, 7(2). https://doi.org/10.31800/jtp.kw.v7n2.p91--103.

Kiong, T. T., Yunos, J. M., Mohammad, B., Othman, W., Heong, Y. M., \& Mohamad, M. M. (2012). The Development and Implementation of Buzan Mind Mapping Module. Procedia - Social and Behavioral Sciences, 64. https://doi.org/10.1016/j.sbspro.2012.11.464.

Kkese, E. (2020). McGurk effect and audiovisual speech perception in students with learning disabilities exposed to online teaching during the COVID-19 pandemic. Medical Hypotheses, 144(July), 110233. https://doi.org/10.1016/j.mehy.2020.110233.

Komikesari, H., Mutoharoh, M., Dewi, P. S., Utami, G. N., Anggraini, W., \& Himmah, E. F. (2020). Development of e-module using flip pdf professional on temperature and heat material. Journal of Physics: Conference Series, 1572(1). https://doi.org/10.1088/1742-6596/1572/1/012017.

Kostiainen, E., Ukskoski, T., Ruohotie-Lyhty, M., Kauppinen, M., Kainulainen, J., \& Mäkinen, T. (2018). Meaningful learning in teacher education. Teaching and Teacher Education, 71, 66-77. https://doi.org/10.1016/j.tate.2017.12.009.

Lage-Cala, S., Folgueras-Díaza, M. B., Alonso-Hidalgoa, M., García-Menéndezb, D., \& Fernández-Garcíab, F. J. (2020). Investigation of the effectiveness of online learning tools for energy performance certificates preparation. Energy Reports, 6, 609-614. https://doi.org/10.1016/j.egyr.2019.09.034.

Lee, T. T., \& Osman, K. (2012). Interactive Multimedia Module in the Learning of Electrochemistry: Effects on Students' Understanding and Motivation. Procedia - Social and Behavioral Sciences, 46. https://doi.org/10.1016/j.sbspro.2012.05.295.

Liu, X., Kong, J., Jiang, M., \& Li, S. (2021). Interactive information module for person re-identification. Journal of Visual Communication and Image Representation, 75. https://doi.org/10.1016/j.jvcir.2021.103033.

Lukman, \& Ishartiwi. (2014). Pengembangan Bahan Ajar Dengan Model Mind Map Untuk Pembelajaran Ilmu Pengetahuan Sosial SMP. Jurnal Inovasi Teknologi Pendidikan, 1(2). https://doi.org/10.21831/tp.v1i2.2523.

Martha, N. U., \& Andini, N. P. (2019). Pengembangan Bahan Ajar Mata Pelajaran Bahasa Indonesia Berbasis $\begin{array}{lllll}\text { Cerita Rakyat } \quad \text { Kabupaten } & \text { Banjarnegara. }\end{array}$ https://doi.org/10.22219/jinop.v5i2.9992.

Mastroleo, N. R., Humm, L., Williams, C. M., \& Kiluk, B. D. (2020). Initial testing of a computer-based simulation training module to support clinicians' acquisition of CBT skills for substance use disorder treatment. Journal of Substance Abuse Treatment, 114. https://doi.org/10.1016/j.jsat.2020.108014.

Neppala, P., Sherer, M. V., Larson, G., Bryant, A. K., Panjwani, N., Murphy, J. D., \& Gillespie, E. F. (2018). An interactive contouring module improves engagement and interest in radiation oncology among preclinical medical students: Results of a randomized trial. Practical Radiation Oncology, 8(4). https://doi.org/10.1016/j.prro.2018.01.001.

Ningsih, S. Y., \& Mahyuddin, N. (2021). Desain E-Module Tematik Berbasis Kesantunan Berbahasa Anak Usia Dini di Taman Kanak-Kanak. Jurnal Obsesi: Jurnal Pendidikan Anak Usia Dini, 6(1), 137-149. https://doi.org/10.31004/obsesi.v6i1.1217.

Nisa, W. L., Ismet, I., \& Andriani, N. (2020). Development of E-Modules Based on Multi-representations in Solid-State Physics Introductory Subject. Berkala Ilmiah Pendidikan Fisika, 8(2), 73. https://doi.org/10.20527/bipf.v8i1.7690.

Nurdyansyah, \& Mutala'liah, N. (2015). Pengembangan Bahan Ajar Modul Ilmu Pengetahuan Alambagi Siswa Kelas IV Sekolah Dasar. Program Studi Pendidikan Guru Madrasa Ibtida'iyah Fakultas Agama Islam Universitas Muhammadiyah Sidoarjo, 41(20), 1-15.

Perdana, Sarwanto, Sukarmin, S., \& Sujadi, I. (2017). Development of E-Module Combining Science Process Skills And Dynamics Motion Material To Increasing Critical Thinking Skills And Improve Student Learning Motivation Senior High School. International Journal of Science and Applied Science, 1(1), 45-54. https://doi.org/10.20961/ijsascs.v1i1.5112.

Priantini, D. A. M. M. O. (2017). Pengembangan Profesi Tenaga Pendidik Dalam Menciptakan Pendidikan Yang Berkualitas. Jurnal Widya Accarya, 8(2), 1-9.

Priantini, D. A. M. M. O. (2021). The Development Of Teaching Video Media Based On Tri Kaya Parisudha In 
Educational Psychology Courses. Journal of Education Technology, 4(4), 448. https://doi.org/10.23887/jet.v4i4.29608.

Purnomo, H., \& Wilujeng, I. (2016). Pengembangan Bahan Ajar dan Instrumen Penilaian IPA Tema Indahnya Negeriku Penyempurnaan Buku Guru dan Siswa Kurikulum 2013. Jurnal Prima Edukasia, 4(1), 67-68. https://doi.org/10.21831/jpe.v4i1.7697.

Purwanto, Y., \& Rizki, S. (2015). Pengembangan Bahan Ajar Berbasis Kontekstual Pada Materi Himpunan Berbantu Video Pembelajaran. AKSIOMA Journal of Mathematics Education, 4(1), 67-77. https://doi.org/10.24127/ajpm.v4i1.95

Puryadi, P., Rahayu, S., \& Sutrio, S. (2018). Pengaruh Model Pembelajaran Direct Instruction Berbantuan Bahan Ajar Berbasis Kontekstual Terhadap Hasil Belajar IPA Terapan Siswa Kelas X SMKN 4 Mataram Tahun Ajaran 2015/2016. Jurnal Pendidikan Fisika Dan Teknologi, 4(1). https://doi.org/10.29303/jpft.v4i1.329.

Qondias, D. Winarta, I, K, A. S. (2019). Pengembangan Bahan Ajar Berbasis Pendekatan Saintifik pada Mata Kuliah Metodologi Penelitian. Jurnal Penelitian Dan Pengembangan Pendidikan, 3(2), 145-148. https://doi.org/doi.org/10.23887/jppp.v3i2.17393.

Sadikin, A., \& Hamidah, A. (2020). Pembelajaran Daring di Tenggah Wabah Covid-19. Jurnal Ilmiah Pendidikan Biologi, 6(2), 214-224. https://doi.org/10.22437/bio.v6i2.9759.

Santika, I. G. N. (2017). Kepala Sekolah Dalam Konsep Kepemimpinan Pendidikan: Suatu Kajian Teoritis. Widya Accarya, 7(1).

Santika, I. G. N. (2018). Strategi Meningkatkan Kualitas SDM Masyarakat Desa Padangsambian Kaja Melalui Pendidikan Karakter Berbasiskan Kepedulian Lingkungan Untuk Membebaskannya Dari Bencana Banjir. Widya Accarya, 9(1).

Santika, I. G. N. (2021). Grand Desain Kebijakan Strategis Pemerintah Dalam Bidang Pendidikan Untuk Menghadapi Revolusi Industri 4.0. Jurnal Education and Development, 9(2), 369-377.

Santika, I. G. N., Kartika, I. M., Ayu, I. G., \& Darwati, M. (2021). Reviewing The Handling Of Covid-19 In Indonesia In The Perspective Of The Pancasila Element Theory ( TEP ). Jurnal Etika Demokrasi (JED), 6(2), 40-51. https://doi.org/10.26618/jed.v6i2.5272.

Seruni, R., Munawaroh, S., Kurniadewi, F., \& Nurjayadi, M. (2020). Implementation of e-module flip PDF professional to improve students' critical thinking skills through problem based learning. Journal of Physics: Conference Series, 1521(4), 1-6. https://doi.org/10.1088/1742-6596/1521/4/042085.

Setiyani, Putri, D. P., Ferdianto, F., \& Fauji, S. H. (2020). Designing a Digital Teaching ModuleBased on Mathematical Communication in Relation and Function. Journal on Mathematics Education, 11(2), 223-236. https://doi.org/10.22342/jme.11.2.7320.223-236.

Sidiq, R., \& Najuah. (2020). Pengembangan E-Modul Interaktif Berbasis Android Pada Mata Kuliah Strategi Belajar Mengajar. Jurnal Pendidikan Sejarah, 9(1), 1-14. https://doi.org/10.21009/JPS.091.01.

Silalahi, M. V. (2020). Development of E-Modules Based on Exe-Learning on Topics of Reaction Rate Against Student Learning Outcomes Mechanical Engineering. International Journal of Education and Curriculum Application, 3(2), 114-120. https://doi.org/10.31764/ijeca.v3i2.2672.

Sriyanto, Leksono, \& Harwanto. (2019). Bahan Ajar PPKn Berbasis Karakter dan Literasi Untuk Siswa Kelas IX SMP Al Hikmah Surabaya. Edmotech, 4(2), 130-142. http://dx.doi.org/10.17977/um039v4i22019p130.

Suzuki, S. N., Akimoto, Y., Suzuki, K., Okada, A., Hirata, K., Kato, T., Yajima, K., Kanematsu, H., Fukumoto, T., \& Yoshikawa, F. (2020). Development of A-txt system compatible introductory teaching materials for Electric Power Engineering using gaming simulation. Procedia Computer Science, 176, 1557-1566. https://doi.org/10.1016/j.procs.2020.09.167.

Swarniti, N. W. (2021a). A Corpus Based Approach to the Analysis of Structures in Prepositional Phrase. Yavana Bhasha: Journal of English Language Education, 4(1), 18-22. http://dx.doi.org/10.25078/yb.v4i1.2207.

Swarniti, N. W. (2021b). The Analysis of Semantics Meaning Found In Comments of Instagram Account of Info Denpasar. Prosiding Seminar Nasional Linguistik Dan Sastra (SEMNALISA), 193-199.

Thuneberg, H. M., Salmi, H. S., \& Bogner, F. X. (2018). How creativity, autonomy and visual reasoning contribute to cognitive learning in a STEAM hands-on inquiry-based math module. Thinking Skills and Creativity, 29. https://doi.org/10.1016/j.tsc.2018.07.003.

Triwahyuningtyas, D., Ningtyas, A. S., \& Rahayu, S. (2020). The problem-based learning e-module of planes using Kvisoft Flipbook Maker for elementary school students. Jurnal Prima Edukasia, 8(2), 199-208. https://doi.org/10.21831/jpe.v8i2.34446.

Tsai, H. C., Jou, M., Wang, J. Y., \& Huang, C. C. (2017). An empirical study on the incorporation of APP and progressive reasoning teaching materials for improving technical creativity amongst students in the subject of automatic control. Computers in Human Behavior, 75, 997-1007. https://doi.org/10.1016/j.chb.2016.10.031. 
Weriyanti, W., Firman, F., Taufina, T., Taufina, T., \& Zikri, A. (2020). Pengembangan Bahan Ajar Tematik Terpadu dengan Strategi Question Student Have di Sekolah Dasar. Jurnal Basicedu, 4(2), 476-483. https://doi.org/10.31004/basicedu.v4i2.374.

Wulandari, Sudatha, \& Simamora. (2020). Pengembangan Pembelajaran Blended Pada Mata Kuliah Ahara Yoga Semester II di IHDN Denpasar. Jurnal Edutech Undiksha, 8(1), 1-15. http://dx.doi.org/10.23887/jeu.v8i1.26459. 